\title{
PENDEKATAN KONSELING SEBAYA TEPAT GUNA UNTUK GENERASI MELLINIAL DALAM PERUBAHAN SOSIAL BUDAYA
}

\author{
Oleh : \\ Prof. Dr. Firman. MS. Kons \\ (Jurusan Bimbingan dan Konseling Fakultas IImu Pendidikan Univ. Negeri Padang) \\ Email : firman@konselor.org
}

\begin{abstract}
Abstrak
Hubungan sosial generasi mellinial jauh berbeda dengan generasi sebelumnya. Generasi mellinial mengidentifikasi teman sebaya dari berbagai tempat didasarkan oleh keinginan untuk memenuhi kebutuhan dengan memanfaatkan teknologi digital. Tulisan ini mengupas pendekatan konseling sebaya tepat guna untuk generasi mellinial dalam perubahan sosial budaya. Konseling sebaya di era melinium 4.0 menuntut perubahan sesuai dengan kebutuhan generasi mellinial. Perubahan pola relasi yang sebagian besar menggunakan teknologi digitas menuntut perubah dalam pelaksanaan konseling sebaya. Peningkatan keterampilan konselor sebaya dengan pendekatan terapi realitas mengikuti kemajuan teknologi serta mengembangan kompetensi konseli mengambil peluang di era milinium 4.0 sangat diharapkan. Pendekatant terapi realitas berasumsi bahwa manusia berjuang untuk mengontrol kehidupan dalam upaya memenuhi kebutuhan.
\end{abstract}

\section{A. PENDAHULUAN}

Generasi mellinial disebut juga dengan generasi Y, yang merupakan generasi lahir kira-kira tahun 1981 sampai1994, sebagian penulis ada juga menyebutkan lahir dari tahun 1981 sampai tahun 2000 an. Generasi mellinial sebagian besar menggunakan teknologi komunikasi instan dalam kehidupannya, seperti: e-mail, SMS (Short Message Service), instan messaging, media social, dan menyukai game on-line. Sebelum generasi mellinial, ada generasi Baby Boomers / Generasi X yang lahir tahun 1965 sampai tahun 1980. Kehidupan generasi mellinial dibadingkan generasi Baby Boomers/generasi X jauh berbeda. Generasi X dibesarkan dalam kondisi masyarakat yang hierarkhis dan sistem kerjasama didasarkan oleh tuntutan pekerjaan. Generasi Mellinial sebagian besar telah mememiliki pendidikan lebih baik dan terbiasa dengan teknologi, percaya diri, bekerja dengan kreatif dan mempunyai semangat mencapai suatu tujuan (Ambarwati, Raharjo, Semarang, Kepolisian, \& Milenial, 2018).

Dewasa ini di lingkungan dunia kerja, generasi mellinial mencapai 50 persen serta diperkirakan tahun 2030 secara global berjumlah sebanyak 75 persen. Kelebihan generasi mellinial, yaitu (1) dapat melakukan berbagai kegiatan dalam waktu bersamaan dan tetap mengejar deadline, (2) kreativitas dengan mengutamakan persamaan, sedangkan perbedaan usia serta kelas sosial tidak menjadi perhatian, (3) kritis dan berusaha 
membandingkan kondisi nyata dengan dunia maya, serta (4) berkontribusi dengan cara berbeda (Dwiyun Evi Yolanda, Isti Mulyan, n.d.). Sedangkan kelemahan generasi mellinial, yaitu : (1) berorientasi kepada produk, serba instan dan memandang semua pekerjaan dipermudah oleh teknologi, kurang menghargai proses, kurang memiliki semangat juang dan kurang tangguh menghadapi permasalahan, (2) kurang mematuhi etika yang sudah mapan, (3) permisif, terbuka terhadap perubahan, tidak jarang kebablasan menginterpretasi sesuatu yang selama ini dianggap tabu dan akhirnya menjadi hal yang biasa, (4) keterampilan sosial rendah dan terkesan kurang beretika dan tidak terlatih berkomunikasi secara langsung (Dwiyun Evi Yolanda, Isti Mulyan, n.d.) .

Oktavianus (2017) menjelaskan karakteristik generasi mellinial, yaitu (1) rasa percaya diri, (2) optimistis, (3) ekspresif, (4) bebas, dan (5) menyukai tantangan. Kondisi keseharian generasi mellinial menjalani secara terbuka dengan pembaharuan dan ingin tampil beda, kreatif, menyukai suasana kerja yang santai serta mampu mengerjakan beberapa tugas secara bersamaan, peduli terhadap gaya, cepat beradaptasi dengan teknologi.

Generasi mellinial tidak jarang mengalami berbagai permasalahan, diantaranya gampang bosan dan kurang memiliki loyalitas terhadap pekerjaan (Suryadi, 2015;M. Subandowo, 2017). Sebagian generasi milinial ditemukan adiksi gadget, kurang fokus dalam belajar, emosi mereka kurang stabil, pornografi, pergaulan bebas dan memunculkan degradasi moral dan kebebasan bergaul (Munir, 2018). Permasalahan tersebeut membuat generasi millinial rentan akan social media harassment, hingga menimbulkan persoalan cybercrime yang berpengaruh terhadap kematangan perkembangan kognitifnya. Media sosial bagi generasi mellinial tidak hanya berperan sebagai online interaction, tetapi juga tempat komunikasi politik (Retnayu Prasetyanti, 2017).

Perubahan tingkah laku generasi mellinial dipicu oleh perubahan sosial yang sedang mengubah cara hidup masyarakat dari berbagai segi. Berbagai aktifitas menjadi serba digitalisasi dan otomasi serta kegiatan tatap muka beralih ke on line. Perbelanjaan secara konvensional beralih ke on line dan sistem pembayaran melalui e-banking semakin digandrongi (Susanto, 2015). Pembayaran tunai diganti oleh e-money dan industri percetakan mulai hilang digantikan oleh media on line. Semua kegiatan serba digital dan sistem siber-fisik mengawasi proses fisik, menciptakan salinan dunia fisik secara virtual serta membuat keputusan yang tidak terpusat. 
Interaksi antar individu serta kelompok sosial lainnya di era mellinium 4.0 mengalami perubahan tanpa batas ruang serta waktu. Perilaku berbasis media sosial dalam kehidupan sehari-hari semakin berkembang. Efesiensi dan efektifitas sebagai akibat dari perubahan sosial di era Revolusi Industri 4.0 mempunyai potensi untuk mendorong perkembangan serta meningkatkan kesejahteraan. Kesempatan generasi mellinial semakin meningkat untuk memasuki kegiatan inkubasi dan akselerasi social entrepreneurs serta investor dalam membangun jejaring serta kemitraan dalam berbagai kegiatan sosial ekonomi menuju perkembangan serta kesejahteraan masyarakat (Syamsuri \& Ishaq, 2010).

Perubahan-perubahan di era Revolusi 4.0 memberi peluang baru untuk mendorong perkembangan generasi mellinial dan masyarakat untuk memenuhi kebutuhan hidup. Revolusi Industri 4.0 bila tidak dicermati lebih lanjut, juga akan menimbulkan dampak negatif yang mengakibatkan terjadinya penurunan, pengerdilan serta keterlambatan perkembangan generasi dan masyarakat. Kondisi ini selanjutnya menyebabkan terganggunya kepentingan dan kohesi sosial serta relasi yang sudah mapan di lingkungan generasi mellinial serta masyarakat. Pengangguran, kerusakan alam dan berkembangnya hoax akan menganggu keberlangsungan hidup generasi mellinial.

Di sisi lain, Revolusi 4.0 membawa dampak terhadap pendidikan dan pelaksanaan bimbingan konseling di sekolah, dari berbagai jenjang serta tingkat yang memerlukan kreativitas pendidik dan tenaga kependidikan lainnya, termasuk di dalamnya Guru BK/Konselor Sekolah dalam menyiapkan peserta didik/konselee yang berkembang secara optimal di era milinium 4.0. Salah satu kegiatan yang dapat dimanfaatkan oleh Guru $\mathrm{BK} /$ Konselor Sekolah dalam kegiatan tersebut, yaitu konseling teman sebaya.

Konseling sebaya diberikan di sekolah dengan pertimbangan siswa di Sekolah Menengah berada pada periode remaja yang sedang menghadapi berbagai permasalahan menuju perkembangan secara optimal, baik dari segi fisik, sosial, emosional, moral, akademik, dan spiritual. Remaja di sekolah menengah mengahadapi permasalahan berhubungan dengan penyesuaian sosial dengan teman sebaya. Konseling sebaya yang dilaksanakan di sekolah merupakan proses pemberian bantuan yang dijembatani oleh siswa lainnya. Sehubungan dengan hal itu, Guru BK/Konselor Sekolah memilih siswa sebagai relawan yang akan berperan aktif terlebih dalam kegiatan bimbingan konseling. Konselor sebaya bukanlah ahli professional akan tetapi siswa yang dipilih dan diberi pelatihan khusus membantu mengentaskan masalah siswa oleh Guru BK/Konselor Sekolah (Kadarsih,2017.) 
Konseling teman sebaya diera melinium 4.0 menuntur perubahan, mengigat siswa di sekolah telah memanfaatkan teknologi informasi melalui internet dalam kehidupan sehari-hari. Sebagian siswa pengguna internet tersebut mengalami kesulitan melakukan aktivitas yang mendukung perkembangannya, sehingga mudah terpengaruh sehingga muncul berbagai permasalahan sebagai akibat dari tindakan pelanggar aturan, etika serta moral. Berdasarkan uraian tersebut, menarik dibahas lebih lanjut melalui tulisan ini bagaimana pendekatan konseling sebaya tepat guna untuk generasi mellinial yang religius.. Pengungkapan permasalahan tersebut bermanfaat untuk merumuskan pola baru dalam pengembangan pelayanan bimbingan dan konseling sesuai dengan kebutuhan peserta didik di era milinium 4.0.

\section{B. PERUBAHAN SOSIAL DAN KONSELING SEBAYA DI ERA MILINIUM 4.0}

Disruptif sebagai akibat dari perubahan sosial budaya di lingkungan masyarakat, mendorong terbukanya kesempatan baru bagi Guru BK/Konselor Sekolah merumuskan pola baru dalam pelaksanaan bimbingan dan konseling sesuai dengan kebutuhan generasi mellinial. Disruptif diawali oleh ketidak pastiaan karena tuntutan berinovasi secara terus menerus mengikuti perkembangan masyarakat dalam kehidupan ekonomi (Lasmawan, n.d.) Disrupsi telah membawa dampak ke dalam berbagai bidang kehidupan sosial dan budaya, termasuk bimbingan konseling. Pengelolaan bimbingan konseling diharapkan berlangsung secara efektif dan efisien. Perkembangan teknologi informasi memunculkan conseling on line dan pola relasi antar individu serta kelompok dalam dunia konseling mulai berubah. Perubahan pola relasi semakin dipicu dengan perkembangan media sosial yang memberi warna baru dalam kehidupan sosial peserta didik.

Perubahan pola relasi di Era Mellinium 4.0 menuntut perubah dalam pelaksanaan bimbingan konseling, dengan mengadopsi kegiatan-kegiatan bercirikan penggunaan teknologi digital serta proses pembelajaran dengan sistem siber (cyber system). Peningkatan keterampilan Guru BK/Konselor Sekolah serta konselor sebaya mengikuti kemajuan teknologi serta mengembangan konsele mengambil peluang dari perkembangan teknologi dan informasi di era milinium 4.0. Peran utama Guru BK/Konselor Sekolah, dalam hal ini merumuskan berbagai jenis layanan bimbingan konseling menyiapkan generasi milenial menjadi angkatan kerja yang kompetitif dan produktif. Guru BK/Konselor Sekolah diharapkan merumuskan road map pelaksanaan bimbingan dan konseling di sekolah yang mengacu kepada peta jalan (road map) pemerintah, berjudul Making Indonesia 4.0. 
Pemerintah Indonesia telah merumuskan road map yang menetapkan arah masa depan industri utama nasional,yaitu : industri makanan dan minuman, tekstil, otomotif, elektronik, dan kimia (Ridhwan et al., 2015).

Pelaksanaan bimbingan konseling, menuntut Guru BK/Konselor Sekolah mengembangkan pola digital sesuai dengan kebutuhan generasi mellineal. Pengembangan pola digital diperlukan untuk mendorong generasi milenial meningkatkan keterampilan digital agar berfungsi dikemudian hari sebagai pekerja yang menguasai sejumlah bahasa asing, yang pada gilirannya dapat berinteraksi dengan masyarakat global.

Pengembangan kompetensi peserta didik/konselee menggunakan teknologi digital membutuhkan dukungan melalui penyesuaian layanan bimbingan konseling dengan perubahan/ tantangan serta kebutuhan di Era Milinium 4.0. Penyiapan Guru BK/Konselor Sekolah masa silam dibandingkan kebutuhan siswa/konseli di Era Milinia 4.0 jauh berbeda. Generasi millinia dihadapkan oleh perubahan relasi dari konvensional ke on line secara terintegrasi dan otomatik. Persaingan dengan kompetensi unggul dalam mewujudkan impian dan harapan menuntut Sumber Daya Manusia (SDM) yang memiliki disiplin yang tangguh menghadapi persoalan. (Firman, 2016).

Kebutuhan generasi mellinial di Era Milinium 4.0, menuntut Guru BK/Konselor Sekolah secara terus menerus belajar keterampilan digital melalui jalur pra jabatan serta dalam jabatan, sehingga dapat memenuhi kebutuhan generasi mellinial. Guru BK/Konselor Sekolah yang tidak berkesempatan mengembangkan diri akan terjadi kesenjangan dengan peserta didik/konselee. Kondisi ini akan menyebabkan kualitas layanan bimbingan dan konseling di Sekolah semakin tertinggal dibandingkan negara lain yang telah siap menghadapi perubahan era Milinium 4.0.

Konselee di di Era Milinium 4.0 memungkinkan untuk mendapatkan berbagai pengetahuan serta keterampilan melalui teknologi komunikasi digital secara otomatik. Pengetahuan dan keterampilan yang mereka peroleh tidak jarang mengesampingkan muatan psikologis berkaitan sikap, moral serta etika hubungan sosial lainnya. Keberagaman konselee beserta berbagai permasalahan dialaminya, memerlukan pendekatan layanan bimbingan dan konseling berorientasi kepada peserta dididik menjadi primadona. Layanan bimbingan dan konseling selama ini didominasi oleh Guru BK/Konselor Sekolah semakin berkurang dan pendidikan karakter serta literasi diharapkan menghasilkan konseli yang bijaksana dalam menggunakan teknologi .

Konseli di Era Milinium 4.0, diharapkan memiliki keterampilan, yaitu : berpikir kritis dan pemecahan masalah (critical thinking and problem solving skill), (2) 
komunikasi dan kolaboratif (communication and collaborative skill. (3) berpikir kreatif dan inovasi (creativity and innovative skill). (4) literasi teknologi informasi dan komunikasi (information and communication technology literacy), (5) literasi teknologi informasi dan komunikasi (TIK), (6) contextual learning skill, (7) literasi informasi dan media (information and media literacy) (Ratna Hidayah1, Moh. Salimi2, 2017).

Penyiapkan peserta didik/konseli dengan kompetensi yang dapat mengambil peluang dalam perubahan di era Revolusi Industri 4.0 tidak dapat dilakukan sepenuhnya oleh Guru BK/Konselor sekolah mengigat jumlah siswa yang dilayani serta kedekatan hubungan sosial karena berbeda generasi. Sehubungan dengan hal itu, Guru BK/Konselor Sekolah dapat memanfaatkan konselor sebaya melalui pelaksanaan konseling sebaya (peer caunseling).

Konseling sebaya merupakan proses pemberian bantuan sesama teman sebaya secara interpersonal yang dilaksanakan oleh individu yang telah mendapat perlatihan sebelumnya dari Konselor/Guru BK di sekolah. Konselor sebaya bukan profesional tetapi teman sebaya yang melaksanakan fungsi mediasi antara siswa dengan Guru BK/ Konselor Sekolah dalam pelaksanaan bimbingan dan konseling. Keterampilan yang diperlukan Konselor sebaya, menyangkut dengan keterampilan mendengar secara aktif, berempati dan memiliki wawasan membantu individu lain sebagai teman sebayanya dalam menyelesaikan permasalahan.

Carr (1981) menjelaskan terdapat sembilan kontribusi penting konseling sebaya untuk dikembangkan, yaitu (1) hanya sebagian kecil dari siswa yang bersedia untuk berkonsultasi dengan konselor, (2) adanya interaksi-interaksi dengan keterampilan sederhana efektif membantu siswa, (3) teman sebaya memungkinkan membantu menyelesaikan permasalahan siswa lainnya, (4) konseling teman sebaya dapat memperkuat siswa dalam menghadapi kondisi psikologis, (5) siswa perlu memiliki kompetensi untuk saling memahami dan bertanggung-jawab tentang peran mereka bagi orang lain, (6) siswa ingin meraih kebebasan melalui sudut pandang budaya teman sebaya, (7) hasil penelitian menunjukkan teman sebaya dapat meningkatkan prestasi dan kepercayaan diri siswa, (8) teman sebaya sebagai tempat berbagi dan memiliki perhatian yang sama dalam memecahkan masalah, (9) teman sebaya lebih mengetahui permasalahan yang dialami mereka sendiri dibandingkan yang dirasakan orang dewasa (Thrisia Febrianti, 2017) .

Konselor sebaya dalam pelaksanaan konseling sesuai kebutuhaan generasi mellinial diharapkan dapat mengubah tingkah laku teman sebaya lainnya sebagai konseli 
melalui relasi secara digital dan konvensional. Selama proses konseling sebaya berlangsung, konselor sebaya dapat memberikan reinforcement untuk memberikan penguatan melakukan sesuatu tindakan dalam penyelesaian permasalahan yang mereka hadapi. Secara prinsipil konseling sebaya merupakan proses pemberian bantuan yang bersifat interpersonal dilakukan oleh pihak nonprofessional, dibawah bimbingan professional Guru BK/Konselor Sekolah.

Konseling sebaya di era melinium 4.0 menuntut perubahan sesuai dengan kebutuhan generasi mellinial. Perubahan pola relasi yang sebagian besar menggunakan teknologi digitas menuntut perubah dalam pelaksanaan konseling sebaya. Peningkatan keterampilan konselor sebaya mengikuti kemajuan teknologi serta mengembangan kompetensi konseli mengambil peluang di era milinium 4.0 sangat diharapkan.

\section{KONSELING SEBAYA TEPAT GUNA UNTUK GENERASI MELLINIAL}

Generasi mellinium mempunyai karakteristik berbeda dengan generasi sebelumnya yang ikut menentukan pola relasi dalam pelaksanaan konseling sebaya. Generasi millenial telah berpengalaman menggunakan teknologi digital untuk kegiatan membaca berita di media cetak, elektronik, digital, jejaringan sosial dan berita lainnya, mendengarkan dan merekam musik, melihat/membuat dan mempublikasikan berbagai pesan. Generasi millenial juga telah terbiasa hidup bertoleransi, berani mengambil resiko, menghargai waktu, mencari informasi di seluruh dunia dan menggunakan tautan hypertext untuk mempelajari sesuatu (Syamsuri \& Ishaq, 2010).

Perbedaan karakteristik generasi mellinial dengan generasi sebelumnya menuntut perbedaan dalam pelaksanaan konseling sebaya. Karakteristik generasi millenial, antara lain : keinginan memegang kendali, tidak mau mengikat diri dengan hal bersifat sekunder, kurang menyukai duduk di dalam ruangan untuk belajar/bekerja, menggunakan teknologi untuk belajar/ bekerja dengan kreatif, membutuhkan berbagai metode dalam menyelesaikan berbagai persoalan dan tantangan, berorientasi dengan kelompok dan kegiatan sosial, melakukan kegiatan belanja dan bermain bersama. Mengidentifikasi teman-teman sesuai kebutuhan secara on line dan bergabung dalam komunitas tertentu, bergaul dengan rekan-rekan di seluruh dunia secara on line (Putra, 2016).

Kebutuhan generasi mellinial akan layanan konseling sebaya berbeda dengan generasi sebelumnya. Program dan kegiatan konseling sebaya dituntut beradaptasi sesuai dengan karakteristik serta kebutuhan generasi mellinial. Program dan model layanan 
bimbingan dan konseling yang dibutuhkan lebih banyak menggunakan teknologi digital (online). Model dan pendekatan layanan bimbingan dan konseling tidak bisa diberlakukan sama generasi sebelumnya.

Guru BK/Konselor Sekolah dituntut secara kreatifitas memanfaatkan inovasi yang ada dalam pelaksanaan konseling sebaya sesuai kebutuhan generasi mellenium. Pengembangan konseling sebaya diawali oleh kegiatan pemilihan calon konselor sebaya, kegiatan sosialisasi serta menjaring siswa yang berminat sesuai dengan kriteria yang diharapkan oleh Guru BK/Konselor Sekolah sesuai dengan kebutuhan generasi mellinial. Beberapa kriteria yang diperlukan konselor sebaya menyangkut dengan empati, keinginan membantu orang lain (motif altruistik), pengalaman serta kematangan sosial dan emosional serta penguasaan keterampilan digital. Pengungkapan kriteria tersebut dapat dilakukan oleh Guru Pembimbing/Konselor Sekolah melalui penggunaan inventori, angket serta wawancara dan observasi. Pengungkapan kriteria sebagai konselor sebaya, sebaiknya dapat dijadikan dasar membangkitkan keyakinan diri membantu orang lain dengan cara dan teknik tertentu sesuai kebutuhan generasi mellinial.

Tindall (Suwarjo,2008) menjelaskan keterampilan yang seharusnya dimiliki oleh konselor sebaya, yaitu : pertama kemampuan memperhatikan serta berempati, menangkap permasalahan, keterampilan mengajukan pertanyaan untuk mengali permasalahan, konfrontasi, dan problem solving. Kemampuan memberikan perhatian (Attending respone) ditujukan untuk memperhatikan konseli, sehingga konselor sebaya dapat menampilkan sikap, tingkah laku serta ekspresi wajah yang menerima secara terbuka, tulus ikhlas dengan mengamalkan prinsip, dasar-dasar konseling. Respon yang dapar diberikan oleh konselor sebaya dalam kondisi ini berupa verbal maupun non verbal. Respon penerimaan konselor sebaya sehingga timbul keinginan untuk dibantu dalam penyelesaian permasalahan dialaminya.

Keterampilan $\boldsymbol{k} \boldsymbol{e} \boldsymbol{d u a}$ yang harus dimiliki konselor sebaya, yaitu kemampuan berempati (emphatizing) terhadap konseli beserta permasalahan yang dialaminya. Kemampuan berempati yang dimiliki konselor sebaya merupakan kondisi emosional untuk ikut merasakan segala sesuatu yang dialami konseli, dengan perasaan dan pikiran tetap dimiliki oleh konselor sebaya tersebut. Keterampilan $\boldsymbol{k e}$ tiga yang harus dimiliki konselor sebaya, yaitu kemampuan menangkap serta merangkum (summarizing) permasalahan yang dialami konseli. Ketermpilan ke empat, yaitu keterampilan mengajukan pertanyaan (question) untuk menggali permasalahan yang sedang dialami konseli. Seorang konselor sebaya diharapkan memiliki kemampuan untuk mengajukan 
pertanyaan terbuka. Keterampilan ke lima, yaitu keaslian (guneineness), ketulusan serta keikhlasan yang ditampilan dalam bentuk perilaku jujur dan sesuai dengan pikiran, perasaan yang sedang dialami serta diekspresikan melalui perkataan dan tingkah laku konselor sebaya. Kererampilan ke enam, asertif (assertivenes) yaitu kemampuan mengungkapkan perasaan, pendapat serta keyakinan terhadap kesulitan-kesulitan yang dialami dalam menjalankan kehidupan sehari-hari. Keterampilan delapan, yaitu pemecahan masalah (Problem Solving).

Penyiapan konselor sebaya sesuai dengan kebutuhan generasi mellinial dilakukan melalui pelatihan yang diberikan oleh Guru BK/Konselor. Pelatihan konselor sebaya ditujukan agar konselor sebaya dapat mengenali permasalahan konseli serta dapat memberikan ketenangan serta kebahagiaan dalam menjalani kehidupannya. Pemilihan konselor sebaya didasarkan oleh kelebihan yang dimiliki oleh konselor sebaya tersebut, berkomitmen, bertanggung jawab, tulus dan ikhlas, menguasai keterampilan digital serta dapat menjaga kerahasiaan informasi yang telah diterima dari konseli (Dwiyun Evi Yolanda, Isti Mulyan, n.d.).

Erhamwilda (2008) menjelaskant langkah utama dalam pelaksanaan konseling sebaya dalam peningkatan kompetesi intrapersonal calon konselor sebaya, yaitu : pemilihan dan pelatihan konselor sebaya, (2) pelaksanaan konseling yang dilakukan oleh konselor sebaya kepada konseli, (3) konselor sebaya melakukan evaluasi dan follow up dari proses konseling dan (4) guru bimbingan konseling. Kefektifan konseling sebaya terlihat pada pengembangan kepribadian konselor sebaya. Selanjutnya Erhamwilda mengemukakan konseling sebaya yang efektif adalah yang memiliki karakteristik, yaitu mengenal diri sendiri, kompeten, dapat dipercaya, jujur, kekuatan, kehangatan, aktif mendengarkan, sabar dan peka.

Laursen (2005) menjelaskan kelompok teman sebaya yang positif memungkinkan remaja merasa diterima, menguji nilai-nilai baru, dan pandangan-pandangan baru pada diri remaja. Selain itu kelompok teman sebaya yang positif dapat memberikan kesempatan kepada remaja membantu orang lain dan mendorong remaja mengembangkan jaringan kerja untuk saling memberikan dorongan positif(Thrisia Febrianti, 2017)

Teman sebaya dalam pelaksanaan konseling sebaya di era Melinium 4.0 merupakan anak-anak dengan tingkat kematangan serta usia yang kurang lebih sama. Salah satu fungsi terpenting dari kelompok teman sebaya, yaitu memberikan sumber informasi dan komparasi tentang dunia di luar keluarga. Konseli diharapkan melalui 
kelompok teman sebaya dapat menerima umpan balik tentang kemampuan yang telah dimilikinya (Suwarjo, 2008)

Di sisi lain, layanan konseling sebaya di sekolah memerlukan dukungan sarana dan prasarana yang memadai. Pelaksanaan layanan konseling sebaya yang mengembangkan cara berpikir tinggi/higher order thinking skills (HOTS) akan menghasilkan/Konseli berkemampuan berpikir kritis, terampil berkomunikasi, berkolaborasi, berpikir kreatif dan percaya diri sesuai dengan kebutuhan generasi mellinial.

Konselor sebaya diharapkan mampu mengarahkan konseli berpikir kritis, analistis dalam penyelesaian masalah yang mereka hadapi. Layanan konseling sebaya pada hakekatnya membantu perkembangan konseli secara optimal. Konselor sebaya dalam pelaksanaan tugasnya, memerlukan kesiapan berbagai strategi dan pendekatan.

Strategi konselor sebaya dalam pelaksanaan konseling diharapkan dapat: (1) mendorong dan memfasilitasi teman sebaya generasi mellinial menyampaikan ide-ide kreatif dan inovatif, (2) memfasilitasi teman sebaya generasi mellinial untuk memodifikasi ide-ide dalam melahirkan inavasi, (3) memberikan umpan balik serta (4) menggunakan informasi dan pengalaman dalam penyelesaian permasalahan yang dihadapi (Suwarjo,2008).

Pemenuhan kebutuhan generasi mellinial dalam pelaksanaan konseling sebaya, menuntut sekolah menyediakan perangkat lunak, infrastruktur serta dukungan teknis dalam pelaksanaan layanan bimbingan dan konseling. Konselor sebaya juga dituntut menguasai berbagai teknik dan pendekatan sederhana yang dapat melayani keberagaman kebutuhan generasi mellinial. Penguasaan tenknik dan pendekatan sederhana tersebut mendorong perkembangan kemampuan berfikir dalam penyelesaian permasalahan, berprestasi dengan tidak mengabaikan nilai dan moral di masyarakat.

\section{PENDEKATAN TERAPI REALITAS DALAM KONSELING SEBAYA}

Pola relasi teman sebaya generasi mellinial berbeda dengan generasi sebelumnya. Kegiatan dalam berhubungan sosial lebih meluas melalui penggunaan teknologi digital dan sistem siber (cyber system). Hubungan sosial tidak dibatasi oleh ruang dan waktu serta orang dari berbagai lapisan sosial. Generasi mellinial mengidentifikasi teman sebaya dalam berhubungan sosial didasarkan oleh keinginan 
untuk memenuhi kebutuhan. Pendekatant terapi realitas berasumsi bahwa manusia berjuang untuk mengontrol kehidupan dalam upaya memenuhi kebutuhan.

Tingkah laku muncul berhubungan dengan teman sebaya lainya, didasari oleh kekuatan dari dalam diri, yang ditujukan untuk memenuhi kebutuhan dasar individu itu sendiri. Pendekatan terapi realitas memandang individu dalam kehidupannya berusaha memenuhi kebutuhan dasar, yaitu (1) kebutuhan mempertahankan hidup/survival, (2) kebutuhan cinta dan merasa diakui/love and belonging, (3) kebutuhan berkuasa, kuat, beprestasi/ power or achivement, (4) kebutuhan memiliki kebebasaan atau kemandirian/ freedom or independence, (5) kebutuhan kesenangan, kegembiraan/ fun. Setiap remaja generasi mellinial membutuhkan kelima unsur tersebut, yang berbeda satu dengan lainnya.

Glasser menjelaskan kebutuhan akan cinta dan perasaan diakui merupakan kebutuhan paling pokok. Saraf sebagai kontrol sistem, secara terus menerus memonitor keberfungsian perasaan memenuhi kelima kebutuhan tersebut. Pemenuhan kebutuhan berlangsung sepanjang hayat yang dimulai sejak dari lahir sampai dengan meninggal dunia. Apabila hasil menotor tersebut dirasakan sangat baik, selanjutnya perasaan-perasaan tersebut dimasukkan ke tempat tertentu dalam otak individu, disebut dengan "dunia kita yang bermakna".

Kebermaknaan dunia kehidupan merupakan hasil monitor saraf sebagai kontrol sistem remaja mellinial menggunakan teknologi digital dalam berhubungan sosial dengan teman sebaya lainnya. Dunia yang bermakna merupakan inti dari kehidupan. Dunia yang bermakna dialami individu tidak ubahnya bagaikan album gambar, bisa saja sebagian dari gambar tersebut buram. Gambar-gambar tersebut berisi hal-hal yang menjadi prioritas bagi individu dan diperkirakan mengalami kesulitan untuk mengidentifikasi prioritas tersebut.

Setiap tingkah laku merupakan cara yang ditempuh dalam upaya memenuhi kebutuhan. Perilaku diciptakan dari empat komponen yang berbeda, yaitu: tindakan, berfikir, merasa, dan fisiologi. Orang bertingkah laku untuk menutupi gap antara apa yang ia inginkan dengan apa yang ia terima dan yang di dapat.

William Glasser menjelaskan seorang menjadi depresi, pusing, marah dan cemas merupakan bagian dari total perilaku mereka sendiri. Ketika seseorang mengembangkan perilaku yang menyakiti, sebenarnya perilaku tersebut merupakan pilihan dan membuat individu tersebut memperoleh makna dari pilihan diinginkan. 
Konseling pendekatan realitas memandang bahwa pada dasarnya masalah sebagian besar konseli yaitu ketidakpuasan dalam berhubungan dengan orang lain. Sebagian besar permasalahan konseli disebabkan ketidakmampuan menjalin hubungan sosial dengan orang-orang terdekat secara memuaskan. Kebagian konseli ditentukan oleh sejauh mana kemampuan konseli berhubungan dengan orang-orang.

Proses konseling realitas ditujukan untuk membantu konseli, yaitu: mendapatkan hubungan memuaskan dengan orang terdekatnya, (2) memenuhi kebutuhan konseli akan cinta dan memiliki, (3) belajar cara-cara yang lebih baik dalam memenuhi kebutuhan dasarnya. Peran Konselor dalam hal ini, yaitu; (1) menciptakan hubungan yang baik dengan konseli, (2).memberi kesempatan kepada konseli mengevaluasi diri, (c) melindunggi dan memberi pendampingan terhadap konseli. Karakteristik konseling realitas yang perlu diperhatikan konselor, yaitu : (1) memfokuskan perhatian terhadap hubungan sosial yang tidak memuaskan, sebagai penyebab masalah konseli, (2) memfokuskan kepada apa yang dapat dikontrol oleh konseli dalam berhubungan dengan orang lain, (3) konselor tidak perlu terlalu banyak mendengarkan penolakan konseli, kesalahan, kritikannya, karena ini merupakan perilaku-perilaku yang tidak efektif, (4) konseling menekankan kepada pilihan perilaku dan tanggung jawab konseli, (5) menolak transference, (6) konseling difokuskan untuk membahas permasalahan sekarang dan tidak masa lampau, (7) konseling menghindari pembahasan gejala-gejala masalah, (8) konseling menolak perspektif tentang sakit mental.

Bertitik tolak dengan uraian tersebut dapat disimpulkan bahwa konseling sebaya merupakan layanan bantuan konseling yang diberikan oleh teman sebaya yang telah terlebih melalui pelatihan-pelatihan untuk menjadi konselor sebaya. Melalui pelatihan tersebut konselor sebaya telah menguasai dasar-dasar keterampilan meliputi attending, summarizing, geuineness, assertiveness, confrontation dan problem solving. Konselor sebayar bukanlah seorang yang profesional di bidang konseling tapi mereka diharapkan dapat menjadi perpanjangan tangan konselor professional.

Selama pelaksanaan konseling sebaya, konselor bertanggung jawab memberikan pelatihan dalam penguasaan keterampilan, penjelasan tentang standar etik, supervisi, visi, suport serta dukungan lainnya. Judy A. Tindall dan Dean Gray (1985) menjelaskan bebrapa kondisi yang diperlukan dalam pelaksanaan konseling sebaya, yaitu: (1) konselor sebaya yang terlibat dalam program konseling diharapkan terlibat dalam perencanaan, (2) 
rencana program pelatihan yang spesifik sangat penting, (3) pertemuan, worshop yang terbatas tidak tepat untuk menyiapkan konselor sebaya secara efektif, (4) program latihan yang terstruktur dan terpadu sangat diperlukan, (5) konselor sebaya yang telah memiliki kualitas sensitivitas, kehangatan, dan kesadaran terhadap orang lain yang sudah baik akan mendukung untuk menjadi konselor yang efektif, (6) supervisor sangat berarti dalam pemberian tindak lanjut terhadap konseling yang sudah berlansung, . Termasuk untuk memberikan follow up pada peer-counseling yang sedang dijalankan helper, (7) evaluasi dan riset bagian penting mengukur kemajuan kegitan dan permasalahan yang dihadapi, (8) konselor sebaya yang dilibatkan harus tertartarik dengan konsep dan aplikasi konseling sebaya, (9) "Peer counselor" seharusnya menjadi bagian terintegrasi dari keseluruhan program bimbingan konseling secara profesional, (10) aspek Etik dari latihan mesti diajarkan secara tepat dan disupervisi secara

\section{E. KESIMPULAN}

Berdasarkan uraian terdahulu dapat disimpulkan sebagai berikut :

1. Konselor sebaya untuk generasi mellinial diharapkan dapat mengubah tingkah laku teman sebaya generasi mellinial lainnya, melalui relasi secara digital dan konvensional. Konseling sebaya di era melinium 4.0 menuntut perubahan sesuai dengan kebutuhan generasi mellinial.

2. Konselor sebaya diharapkan mampu mengarahkan konseli berpikir kritis, analistis dalam penyelesaian masalah yang mereka hadapi. Layanan konseling sebaya pada hakekatnya membantu perkembangan konseli secara optimal. Konselor sebaya juga dituntut menguasai berbagai teknik dan pendekatan sederhana yang dapat melayani keberagaman kebutuhan generasi mellinial.

3. Generasi mellinial berhubungan sosial menggunakan teknologi digital dan sistem siber (cyber system). Hubungan sosial tidak dibatasi oleh ruang dan waktu serta orang dari berbagai lapisan sosial. Pendekatant terapi realitas berasumsi bahwa manusia berjuang untuk mengontrol kehidupan dalam upaya memenuhi kebutuhan melalui hubungan sosial.

\section{Daftar Kepustakaan}

Ambarwati, A., Raharjo, S. T., Semarang, D. K., Kepolisian, A., \& Milenial, G. (2018). Prinsip Kepemimpinan Character of A Leader pada Era Generasi Milenial, 2, 114-127.

Dwiyun Evi Yolanda, Isti Mulyan, M. J. I. A. (n.d.). Pengaruh Generasi Muda Millenial 
terhadap Karakter Interaksi Sosial Di Masyarakat.

Firman, F. (2016). Peranan Psikologi dan Konseling Dalam Peningkatan Kualitas Sumber Daya Manusia (SDM) Menuju Kesejahteraan Masyarakat Ekonomi Asean, 2(Asean Psychology an counseling 2016), 5-9.

Kadarsih, B. K. S. (PEER C. D. P. P. Remajao. (n.d.). Konseling Sebaya UIN.

Lasmawan, W. (n.d.). Disruption Era dan Dampaknya Bagi Pengembangan Kurikulum.

M. Subandowo. (2017). Peradaban dan Produktivitas dalam Perspektif Bonus Demografi serta Generasi Y dan Z. Sosiohumanika: Jurnal Pendidikan Sains Sosial Dan Kemanusiaan, 10(2), 191-208.

Munir, M. (2018). John Naisbitt, Et. All. High Tech High Touch (Jakarta: Pustaka Mizan, 2002). Lihat juga Zuhal, Visi Iptek Memasuki Milenium III (Jakarta: Universitas Pendidikan Indonesi Pers, 2000). 1, 7(1).

Putra, Y. S. (2016). Theoritical Review:Teori Perbedaan Generasi, (2016), 302.

Ratna Hidayah1, Moh. Salimi2, T. S. S. U. (2017).. Jurnal Taman Cendekia, 1(2), 656-663.

Retnayu Prasetyanti, S. P. (2017). Generasi Millennial Dan Inovasi Jejaring Demokrasi Teman Ahok. Jurnal Polinter, 3(1), 44-52.

Ridhwan, M. M., Wicaksono, G., Nurliana, L., Bary, P., Suryani, T. ., \& Satyanugroho, R. (2015). Analisis Daya Saing Dan Strategi Industri Nasional Di Era Masyarakat Ekonomi Asean Dan Perdagangan Bebas, 111. https://doi.org/10.1016/S0007-1935(17)35243-0

Suwarjo. (2008). Konseling Teman Sebaya (Peer Counseling) untuk Mengembangkan Resiliensi Remaja.

Syamsuri, H. A. S., \& Ishaq. (2010). Makalah : Guru, Generasi Z, dan Pembelajaran Abad 21. Repositori Unismuh.ac.id, 1-15.

Thrisia Febrianti. (2017). Model Konseling Teman Sebaya ( Peer Counseling ) Berbasis Life Skills untukMeningkatkan Perilaku Prososial Siswa SMK di Kota Semarang. 